\title{
Nutritionally Improved Corn Mill Waste (Chaff) with Microbial Protein: An Economic Alternative for Poultry Feed
}

\author{
Tochukwu Vincent Balogu ${ }^{1,2, ~ *, ~ H a d i z a ~ I b r a h i m ~}{ }^{3}$, Dennis Odionyenfe Balogu ${ }^{2}$ \\ ${ }^{1}$ Department of Microbiology, Ibrahim Badamasi Babangida University, Lapai, Nigeria \\ ${ }^{2}$ Department of Food Science and Technology, Ibrahim Badamasi Babangida University, Lapai, Nigeria \\ ${ }^{3}$ Department of Animal Science, Ibrahim Badamasi Babangida University, Lapai, Nigeria \\ Email address: \\ tovin2009@yahoo.com (T. V. Balogu) \\ ${ }^{*}$ Corresponding author
}

\section{To cite this article:}

Tochukwu Vincent Balogu, Hadiza Ibrahim, Dennis Odionyenfe Balogu. Nutritionally Improved Corn Mill Waste (Chaff) with Microbial Protein: An Economic Alternative for Poultry Feed. Advances in Applied Sciences. Vol. 2, No. 2, 2017, pp. 18-22.

doi: $10.11648 /$ j.aas.20170202.11

Received: April 30, 2017; Accepted: May 8, 2017; Published: June 29, 2017

\begin{abstract}
This study designed to enhance the nutritional quality of corn mill waste (CMW) with microbial protein accumulated during submerged fermentation by selected microbial consortium. CMW is the dry, scaly residue of milled corn seed popularly known as chaff. A slurry prepared from a mixture of 1:2 ratio of CMW and hot water $\left(80-95^{\circ} \mathrm{C}\right)$ supplemented with mineral salts were fermented for 7 days with microbial consortium (Candida utilis, Aspergillus niger and Saccharomyces cerevisiae) as starter culture. During fermentation, microbial and physicochemical $(\mathrm{pH}$, temperature and titratable acidity) profile were evaluated. Nutritional composition and preliminary acute toxicity of the dried fermented CMWs were assayed. Results showed that starter culture (67.7\%) and non-starters (33.3\%) persisted in the 7-days fermentation. Titratable acidity and $\mathrm{pH}$ decreased by $34.5 \%$ and $11.1 \%$ respectively, unlike temperature that was relative stable during fermentation. Protein content were significantly increased (74\%); while total carbohydrate decreased (25\%) after fermentation. Fermented CMW had no significant $(\mathrm{P}<0.05)$ acute and subacute toxic impact on birds. There were slight but no significant difference $(\mathrm{P}<0.05)$ on nutritional composition and cost index of fermented CMW and commercial feed (control). Conclusively, Fermented CMW offer a prospective economic alternative as poultry feed for rural regions with abundant CMWs.
\end{abstract}

Keywords: Corn Mill Waste, Microbial Protein, Chaff, Poultry Feed

\section{Introduction}

Corn mill wastes (CMWs) are leftover product of corn mill industries [1]. Popular among the CMWs is the chaff (dry, scaly coating of corn seeds with fragments of cotyledon and endosperm) which is the residue from milling corn seeds into powder. CMWs among other agro wastes (cereal waste, cassava waste) are common feeds used for poultry livestock in rural areas. Though, these feeds are cheap, they are nutritional deficit of required protein quality to support bird optimum growth and meat yield. Chaffs are generally low in protein $(\sim 2.5 \%)$, though mostly supplemented with plant proteins and used as feeds for ruminants as well as poultry and other livestocks [2].
Considering the expensive protein supplements, several literatures have suggested the use of microorganisms for the bioconversion of agrowastes into useful products, especially for livestock feeds [3 - 5]. Previous studies have successfully produced singles cell proteins (SCPs) using series of agrowastes from pineapple kinnow-mandarin, mango, orange, rice, cucumber, banana and wheat. Others include cassava starch, capsicum powder, cotton salks, barley straw, sugar cane bagasse and onion juice [6-11].

Most inexpensive method of conversion of agrowastes to useful products have be predicated on biotechnology. Fungal species (Trichoderma Viride, Saccharomyces cerevisiae, 
Geotrichum Candidum Rhizopus Oryzae, Penicillium foncu, Fusarium solani and Aspergillus niger, etc) have significantly enriched the protein and soluble sugars of agrowastes $[2,11]$. Previous study has shown that dry mass of bacteria yield about $60 \%$ protein and fungi yield upto $40 \%$ protein dry mass [11]. However, the health advantage and stability of proteins from yeast to both man and animals, justifies the choice of the yeast and filamentous fungi used for this study.

Most published studies have successfully enhanced the nutritional (protein content) quality of the agrowastes, however, most of these substrates used as carbon sources are not readily available to rural farmers. Thus, the need to investigate possibilities of cheap and available agro-waste becomes inevitable. Consequently, the concept of this study was to enhance the nutritional quality of corn mill waste using microbial protein.

\section{Material and Methods}

\subsection{Sample Collection}

Corn mill wastes (chaff) purchased from different local corn mill industries within Lapai LGA, Niger state, Nigeria, were weighed, packed in clean sacs and transported to Microbiology laboratory, Ibrahim Badamasi Babandida (IBB)University, Lapai $\left(8.8167^{\circ} \mathrm{N} ; 6.6833^{\circ} \mathrm{E}\right)$. Samples were stored at room temperature prior to fermentation.

\subsection{Preparations of Microbial Consortium / Starter Culture}

Pure colonies of Candida utilis, Aspergillus niger and Saccharomyces cerevisiae obtained from repository of Applied Microbiology laboratory in IBB University were verified in Potato dexteros broth (PDB) with appropriate biochemical assays. Validated isolates were separately subcultured on PDB at ambient temperature for 24 hours. Each of the 24-hour old culture was adjusted to cell concentration of $7 \log 10 \mathrm{cfu} / \mathrm{mL}$ and stored at $4{ }^{\circ} \mathrm{C}$ (ice bag) for fermentation protocol [12]. Starter culture was prepared by mixing each of the individual 24-hour old pure cultures of Candida utilis, Aspergillus niger and Saccharomyces cerevisiae at the ratio of $1: 1: 1(\mathrm{v} / \mathrm{v} / \mathrm{v})$ and designed as microbial consortium.

\subsection{Fermentation Protocol of Corn Mill Wastes}

A clean 750-L capacity bioreactor was loaded with CMWs $(150 \mathrm{~kg})$, treated with $300 \mathrm{~kg}$ of hot distilled water $\left(80-95^{\circ} \mathrm{C}\right)$ with thorough mixing, cooled to ambient temperature and supplemented with mineral salts $(2.25 \mathrm{~kg} \mathrm{NaNO}, 0.375 \mathrm{~kg}$ $\mathrm{CaCl}_{2}, 0.375 \mathrm{~kg} \mathrm{MgSO}_{4} \cdot 7 \mathrm{H}_{2} \mathrm{O}, 0.0075 \mathrm{~kg} \mathrm{FeSO}_{4}, 0.75 \mathrm{~kg}$ $\mathrm{KH}_{2} \mathrm{PO}_{4}$ ). The resultant slurry was homogenised with 15000 $\mathrm{ml}$ of microbial consortium (starter) and fermented for 7 days with 10 hours periodic agitation.

\subsection{Drying and Packaging of Fermented Feeds}

Fermented samples were solar dried to approximate moisture content of $3-7 \%$ by observing a cracking sound when the dried samples were rubbed between the palms [13]. The dried fermented samples were milled into pellets forms and stored in airtight sacs prior analysis.

\subsection{Physicochemical Analysis}

The temperature and $\mathrm{pH}$ of the fermented samples were monitored on site using Hanna instrument $\mathrm{pH}$ and thermometer digital device (GallenKamp London) as described by [14] with slight modifications [12]. After each thorough agitation, probes of the devices (temperature and $\mathrm{pH})$ were dipped into the fermenting CMWs samples for 5 minutes before readings were taken. Data expressed were mean values of triplicate procedure.

\subsection{Titratable Acidity (TA)}

Titratable acidity of the fermented slurry was determined according to method described by [15]. For each assessment, $10 \mathrm{~mL}$ of the samples was titrated drop by drop with $0.1 \mathrm{M}$ $\mathrm{NaOH}$ to $\mathrm{pH} 7.1$, (Hana meter HI-1221, 2009). The value of TA was calculated with the volume of $\mathrm{NaOH}(7.5 \times 0.1 \times$ vol. $\mathrm{NaOH})$ and expressed in $\mathrm{g} / \mathrm{L}$ equivalent to tartaric acid.

\subsection{Proximate Analysis}

Determination of ash, crude protein, fibre, moisture content, crude fat, dry matter, and total carbohydrate values were determined using standard procedures as described by [14] and modified by [16].

\subsection{Preliminary Acute Oral Toxicity Assay}

The method of EPA [17] was used to test the acute oral toxicity of the sampled poultry feeds. A total of 15 healthy birds (2-3 weeks old) were grouped into three subunits of 5 birds each and fed with FF, NFF and CPF for 14 days. Physiological and physicochemical profiles of the birds were compared to standards. The use of experimental animals was in accordance to the IBB University animal ethical committee guidelines.

\subsection{Software Statistical Analysis}

Data generated from physical and chemical assessments were subjected to Analysis of variance (ANOVA), Chi-square and Duncan's Multiple Range Test (Version 8, SAS Institute, Cary, NC, USA) and SPSS software version 15 of 2011. All analyses were done at $95 \%$ confidence level.

\section{Result and Discussion}

Yeasts prevalence within the 7 days fermentation were predominated by starter culture species at $67.7 \%$ and nonstarter culture group accounts for 33.3\% (Figure 1). This study validity the report of [18] which observed less than $100 \%$ prevalence of lactic acid bacteria used as starter culture for sourdough fermentation after 48 hour. It is important to note that starter cultures are microbiota that are primarily prepared to colonize and commence the fermentation 
process. Perhaps, the microbial succession beyond $24 \mathrm{~h}$ accounts for declining prevalence of starter culture.

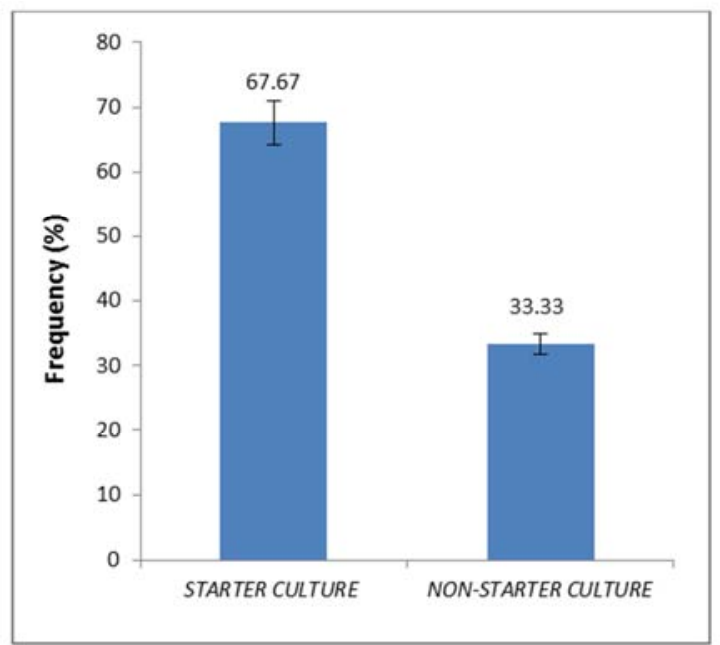

Figure 1. Prevalence of yeast isolated from the fermented corn mill waste (chaff).

Physicochemical parameters ( $\mathrm{pH}$ and titratable acidity) were inversely proportional to fermentation days. $\mathrm{pH}$ and Total titratable acidity (TTA) decreased by $11.1 \%$ (4.05 to 3.60) and $34.5 \%(9.55$ to $6.26 \mathrm{~g} / \mathrm{L})$ respectively. However, temperature was relatively stable at the range of $27.0^{\circ} \mathrm{C}$ to $30.7^{\circ} \mathrm{C}$ (Table 1). Correlation between fermentation days and physicochemical parameters could be good indicators for modeling fermentative kinetics of CMW fermenting system. Trace or absence of volatile compounds (especially acetic acid and $\mathrm{CO}_{2}$ ) in fermenting systems improves the propositional trend between $\mathrm{pH}$ and TTA, and this may account for the trend between $\mathrm{pH}$ and TTA observed in this study.

Table 1. Physiochemical parameters of corn-mill waste during fermentation.

\begin{tabular}{llll}
\hline Days & $\mathbf{p H}$ & Temperature $\left({ }^{\circ} \mathbf{C}\right)$ & TTA $(\mathbf{g} / \mathbf{L})$ \\
\hline Day 1 & $4.05 \pm 0.008$ & $28.46 \pm 0.001$ & $9.552 \pm 0.72$ \\
Day 2 & $3.00 \pm 0.007$ & $30.66 \pm 0.786$ & $6.054 \pm 0.81$ \\
Day 3 & $5.62 \pm 0.481$ & $30.66 \pm 0.792$ & $7.662 \pm 0.14$ \\
Day 4 & $6.16 \pm 0.010$ & $27.33 \pm 2.373$ & $5.877 \pm 1.62$ \\
Day 5 & $3.46 \pm 0.080$ & $28.66 \pm 0.194$ & $8.034 \pm 0.02$ \\
Day 6 & $3.46 \pm 0.116$ & $29.17 \pm 0.236$ & $6.264 \pm 0.71$ \\
Day 7 & $3.60 \pm 0.081$ & $29.00 \pm 0.817$ & $6.255 \pm 0.38$ \\
\hline
\end{tabular}

Proximate analysis showed that fermentation significantly $(\mathrm{P}<0.05)$ increased the total protein content by $74 \%$ while Total carbohydrate reduced by $25 \%$. Protein content of CPF (control) was slightly lower than FF but not significant $(\mathrm{P}>0.05)$. Only ash, fiber and lipid contents of FF were not significantly $(\mathrm{P}>0.05)$ different when compared to both NFF and $\mathrm{CPF}$ (Figure 2).

Protein analysis of the feeds showed that fermentation significantly $(\mathrm{P}<0.05)$ enhanced the protein content of $\mathrm{FF}$ $(110 \mathrm{mg} / \mathrm{g})$ by $36.4 \%$ when compared to the NFF $(70 \mathrm{mg} / \mathrm{g})$. However, CPF (100 mg/g) which was less by $9.1 \%$, was not significantly $(\mathrm{P}>0.05)$ different from FF sample (Figure 3$)$. This validates the result of the proximate analysis on the nutritional variation after fermentation. The theory of microbial protein synthesis and accumulation during fermentation by [19] was further validated. In addition, the microbial consortium used in this study is good fermenter that could unlock digestible soluble sugars from complex carbohydrate to provide adequate energy for protein accumulation.

However, the argument that during microbial growth, some ATPs are redirected toward reserved carbohydrate and energy oozing (heat disperse), which significantly limits cellular protein systhesis [20], perhaps, accounts for the insignificant protein quality of FF compared to $\mathrm{CPF}$ contrarily to the anticipation of the authors.

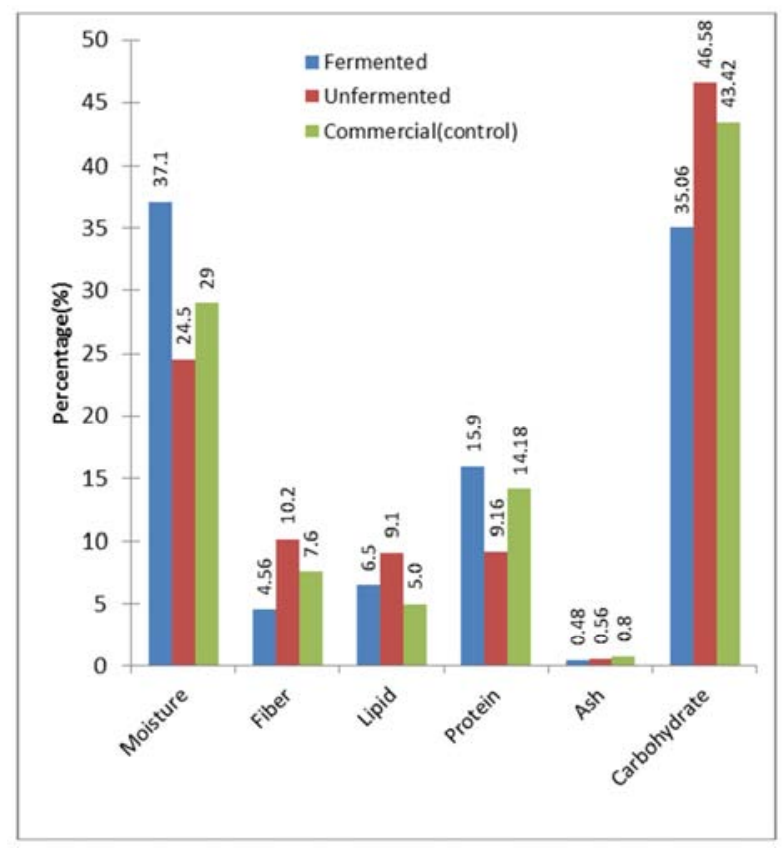

Figure 2. Proximate analysis of different poultry feed.

Notwithstanding, the comparative protein quality of FF was a remarkable nutrient improvement, considering that the main energy source were mostly cellulotic and lignified carbohydrates.

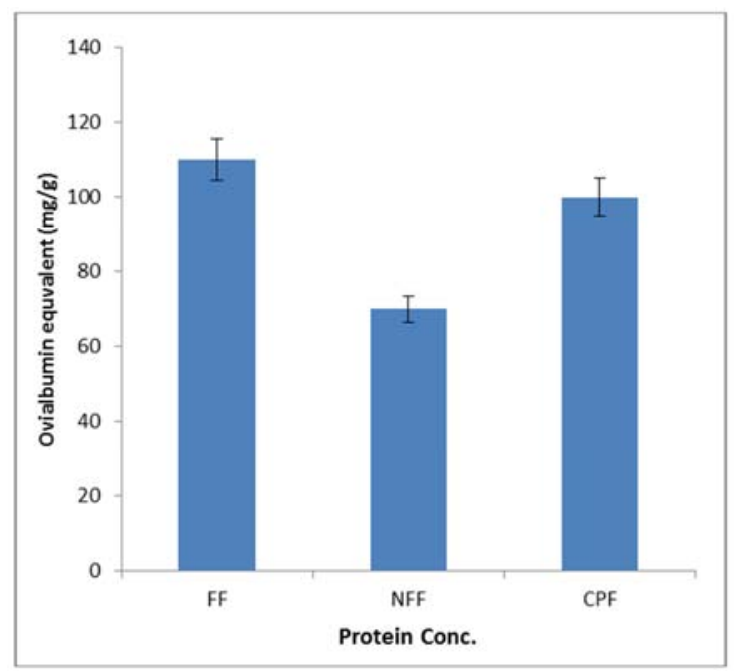

Figure 3. Protein concentration of different feed samples. 
The capability of fungi to degrade cellulose and lignified carbohydrates, and accumulates protein in rumen [21], validates the authors' preference for the fungal consortium used as fermenters.

Preliminary toxicity evaluation of birds fed with the feeds was assessed for 14 days. Results showed that none of the bird died, suggesting that none of the feeds was toxic to the birds. The birds' body temperature $\left(37.0-39.0^{\circ} \mathrm{C}\right)$, stool and behavioural changes were unremarkable and insignificant $(\mathrm{P}>0.05)$ among the three different feeds. Only birds fed with NFF showed a remarkable eye colour (pale) while, FF and CPF fed birds retained normal eye colour (Table 2).

Table 2. Preliminary Acute and Subacute Toxicity of Feeds on Birds for 14 Days.

\begin{tabular}{llllll}
\hline Feed & $\begin{array}{l}\text { Behavioral } \\
\text { changes }\end{array}$ & $\begin{array}{l}\text { Mean } \\
\text { Temp. }\left({ }^{\circ} \mathbf{C}\right)\end{array}$ & $\begin{array}{l}\text { Eye } \\
\text { colour }\end{array}$ & $\begin{array}{l}\text { No of } \\
\text { Death }\end{array}$ & Stool \\
\hline FF & Unremarkable & 38.5 & Normal & Nil & Unremarkable \\
NFF & Unremarkable & 37.0 & pale & Nil & Unremarkable \\
CPF & Unremarkable & 39.0 & normal & Nil & Unremarkable \\
\hline
\end{tabular}

Cost implication of using these three different poultry feeds were shown in table 3. CPF had the best cost index of $0.53 \%$ per $50 \mathrm{~kg}$ of feed, followed by FF $(0.71 \%)$ and the least was NFF with $1.11 \%$. It is important to note that there was no significant difference between cost index of CPF and FF; however, NFF significantly $(\mathrm{P}<0.05)$ differ from both $\mathrm{CPF}$ and $\mathrm{FF}$.

Cost index result indicates that the fermented feed is an economic alternative to commercial poultry feeds available at the local markets. Couple with the high protein quality rating of FF, commercial poultry farms could be managed efficiently in rural regions where CMWs are abundant using FF.

\section{Conclusion}

Fermentation significantly increased nutritional quality (Protein content) of FF by more than 35\%. Selected microbial consortium were efficient in unlocking digestible soluble sugars from complex carbohydrate of the NFF. Based on comparative cost implication assessment, corn mill waste (chaff) is a good resource (agro-waste) that can be utilized as an economic alternative for poultry feed in rural regions with abundant CMWs. The prospect of this study necessitates an extension to investigate the impact of mineral supplements (calcium) and growth performance of birds fed with FF comparable to the CPF.

Table 3. Cost Implication of Poultry Feed (50kg) as at end of year $2016(\$ 1=300)$.

\begin{tabular}{|c|c|c|c|c|c|c|}
\hline Feeds & Feed / Agro-waste (A) & Labour/Trans ( & Mineralsalts ( & Total Cost(\#) & Cost Index (\%) & P-value \\
\hline $\mathrm{CPF}$ & 9000 & 500 & - & 9500 & 0.53 & \\
\hline FF & 4000 & 1500 & 1500 & 7000 & 0.71 & 0.0001 \\
\hline NFF & 4000 & 500 & - & 4500 & 1.11 & \\
\hline
\end{tabular}

NB: Trans $=$ Transportation; $\$=$ US dollar; $\mathbb{N}=$ Nigeria currency unit (Naira) $\mathrm{CPF}=$ Commercial poultry feed; $\mathrm{FF}=$ Fermented Feed; $\mathrm{NFF}=$ Non-fermented Feed Cost index $=[50 \mathrm{~kg}$ of feed/agrowaste $] /[$ Total cost $]$ expressed as percentage .

\section{References}

[1] Joy, D. M. 2014. Effects of Corn mill waste on municipal solid waste degradation in bioreactor landfills. Published Dissertations of Department of civil Engineering, University of Texas at Arlington. Proquest UMI Number1572576. pp 124.

[2] Iyayi, E. A. and Aderolu, Z. A. 2004. Enhancement of the feeding value of some agro- industrial by-products for laying hens after their solid state fermentation with Trichoderma viride. African Journal of Biotechnology 3(3): 182-5.

[3] Bhalla, T. C.; and Joshi, M. 1994. Protein enrichment of apple pomace by co- culture of cellulohytic mould and yeast. World Journal of Microbiology and Biotechnology 10(1):116-7, January.

[4] Abu, O. A.; Oguntimein, G. B.; and Tewe, O. O. 1998. Protein enrichment of sweet potato by solid state fermentation using four mono-culture fungi. Nigerian Journal of Biotechnology 9(1): 1-4.

[5] Adeyemo, S. O.; Akoma, O.; and Adeyeye, A. A. 1999. Improvement of nutritional value of pomace from "KununZaki" production by fermentation with Candida Tropicalis. Nigerian Journal of Biotechnology 10(1): 55-9.
[6] Nigam, N. M. 2000. Cultivation of Candida langeronii in sugarcane bagasse hemi cellulose hydrolysate for the production of single cell protein. World Journal of Microbiology.and biotechnology. 16,367-372.

[7] Tipparat, H. and Kittikun, A. H. 1995. Optimization of single cell protein production from cassava starch using Schwanniomyces castellii. World Journal Microbiology and Biotechnology 11, 607-609.

[8] Abou Hamed, S. A. A. 1993. Bioconversion of wheat straw by yeast into single cell protein.Egypt. Journal of. Microbiology. 28(1), 1-9.

[9] Mondal, K. A., Sengupta, S., Bhowal, J. and Bhattacharya, D. K. 2012. Utilization of fruit wastes in producing single cell Protein. International Journal of Science, Environment and Technology, 1(5): 430 - 438.

[10] Zhao G, Zhang, W., Zhang, G. 2010. Production of single cell protein using waste capsicum powder produced during capsanthin extraction. Letter Applied Microbiology. 50. 18791.

[11] Dhanasekaran, D., Lawanya, S., Saha, S., Thajuddin, N. and Panneerselvam, A. 2011. Production of single cell protein from pineapple waste Using yeast. Innovative Romanian Food Biotechnology. 8: 26-32. 
[12] Balogu, T. V. and Mohammed, H. M. 2017. Production and Sensory evaluation of non-Alcoholic Rice Wine Using Saccharomyces cerevisiae. Journal of Advances in Food Science and Technology, 4(1): 44 - 51.

[13] Amoa-Awua, W., M. Madsen, J. F. Takramah, A. Olaiya, L. Ban-Koffi \& M. Jakobsen 2007: Quality manual for production and primary processing of cocoa. Department of food science, University of Copenhagen Press.

[14] AOAC, 1999. Official Methods of Analysis (15th edn). Association of Official Analytical Chemists, Washington, DC.

[15] Balogu T. V., Abdulkadir, A., Ikegwu, M. T., Akpadolu, B. and Akpadolu K. (2016). Production and Sensory Evaluation of Non-Alcoholic Wine from Sugarcane and Tiger Nut Blend Using Saccharomyces cerevisiae. International Journal of BioSciences, Agriculture and Technology, 7(2): 7-14.

[16] Odebunmi, E. O., Oluwaniyi, O. O. and Bashiru MO 2010. Comparative Proximate Analysis of Some Food Condiments. Journal of Applied Sciences Research, 6(3): 272-274

[17] Environmental protection Agency: EPA. 1992. Pesticide Assessment Guidelines subdivision F: Hazard Evaluation -
Human and Domestic Animals Series 84. Addendum 9 -PB158394.540/09-91-122.

[18] Ravyts, F. and De Vuyst, L. 2011. Prevalence and impact of single-strain starter cultures of lactic acid bacteria on metabolite formation in sourdough. Food Microbiology, 28(6): 1129-1139. doi: 10.1016/j.fm.2011.03.004.

[19] Herrera-Saldana, R.; Gomez-Alarcon, R., Torabi, M. and Huber, J. T. 1990. Influence of Synchronizing Protein and Starch Degradation in the Rumen on Nutrient Utilization and Microbial Protein Synthesis. Journal of Diary Science. 73(1):142-148. 0302(90)78657-2

[20] Hackmann, T. J. and Firkins, J. L. 2015. Maximizing efficiency of rumen microbial protein production. Frontiers of Microbiology 6, 465. doi:10.3389/fmicb.2015.00465.

[21] Valente, T. N.P.; Lima, E. S., Santos, W. B. R., Cesário, A. S., Tavares, C. J. Fernandes, I. L. and Freitas, M. A. M. 2016. Ruminal microorganism consideration and protein used in the metabolism of the ruminants: A Review. African Journal of Microbiology Research. 10(14): 456-464, DOI: 10.5897/AJMR2016.7627. 